\author{
O.G. Yaroshenko ${ }^{1}$, O.A. Blazhko ${ }^{2}$, A.V. Blazhko², T.V. Korshevniuk ${ }^{3}$ \\ ${ }^{1}$ Institute of Higher Education of the National Academy of Educational Sciences of Ukraine, Kyiv, Ukraine; \\ ${ }^{2}$ Vinnytsia Mykhailo Kotsiubynskyi State Pedagogical University, Vinnytsia, Ukraine; \\ ${ }^{3}$ Institute of Pedagogy of the National Academy of Educational Sciences of Ukraine, Kyiv, Ukraine \\ (E-mail: yaroshenko_o@ukr.net)
}

\title{
Group learning activities as a condition of implementing competence-based approach to students' inorganic chemistry teaching at university
}

\begin{abstract}
The article presents the results of experimental testing the effectiveness of group learning activities of students at Inorganic Chemistry laboratory classes. The future teachers had their classes according to a technique based on research paper analysis findings with due account for practice of implementing the concept of group educational activity of senior pupils in Ukraine. The following issues were briefly addressed: special aspects of activities performed by group learning individuals; educational result of inorganic chemistry students presented in the form of general and special (occupational and subject) competences; preparation and order of laboratory classes for small groups of students as subjects. The order, course and results of the pedagogical experiment are presented. The results suggest that using the students' group learning activities is an effective tool for implementation of the competence-based approach to inorganic chemistry educational process, which contributes to lining-up the order and course of inorganic chemistry laboratory practicals. We wish to make a point that using group learning for actualization of the competence-based approach to learning chemistry of students requires certain methodological training of the faculty.
\end{abstract}

Key words: competency-based approach, the Inorganic Chemistry academic discipline, group learning activity, group learning technique, group learning individual, students, academic staff, laboratory practicals.

\section{Introduction}

Teaching based on the competency-based approach is a global trend in higher and secondary education, which has been supported by the United Nations (UN), the Organization for Economic Cooperation and Development (OECD) and other world communities for a long time [1].

The teaching process, which takes into account the above-mentioned trend, is a system of «scientific, methodological and pedagogical measures aimed at the development of a personality by forming and applying his/her competencies» [2]. Based on the foregoing, the policy in the sphere of the national higher education is aimed at the development of general and special (professional, subject) competencies of students [3].

This actualizes the problem of theoretical substantiation and practical implementation of competencebased teaching at higher education institutions. We brought attention to a group learning activity of students in the course of addressing this problem. In order to develop a group learning technique, it was fundamentally important to answer the following questions:

- how to organize a group learning activity of students at inorganic chemistry laboratory practicals;

- what should be done methodologically for successful group learning;

- what is the role of academic staff in this process;

- what educational outcome should we expect.

The analysis of the national scientific sources made it possible to find out that the degree of development of group learning of senior pupils as for the theory and methodology of teaching chemistry is much higher than that of college students. O.G. Yaroshenko substantiated, among other things, the didactic concept of the group learning activity of senior pupils on the basis of chemistry learning using the results of a continuous study of the group learning activities at school [4], and developed a variety of learning and methodological support instructions for teaching senior pupils in small groups [5-10].

A long-term pedagogical experiment $[5,11,12]$ and mass introduction of group learning activity into school practice confirmed its effectiveness.

Our study and the best domestic practices of senior pupil group learning brought us to the conclusion of reasonableness of extrapolation of the main provisions of the high school group learning concept to the teaching process at a college level. It is about approaches to forming small groups, the distribution of roles in a small group, and the ratio of faculty leading role and independence of a group learning individual. However, 
the chemistry teaching process at college level, types and duration of educational classes, the chemistry learning goals, and the age characteristics of students differed significantly. That's why the possibility of a mechanical transfer of a competence-based educational paradigm prevailing at the high school to the college level is excluded. This fact brings a new problem, which consists in the necessity of theoretical substantiation and methodological support to using group learning didactic potential for shaping general and subject competencies of future teachers based on the experience of group learning at high school. We commenced solving this problem with the analysis of previous relevant domestic and international surveys.

Domestic researchers focus mostly on using student group learning activities for development of collaborative communication skills, consider it as a framework for trainings, brainstorms, business games, educational projects, etc. [13-16].

Foreign researchers make an accent on learning, educational, social and organizational functions of group classes, and contemplate the conditions for effectiveness thereof (comprehension of a collaborative objective by a group member, correct lineup of the group in which each member has a positive experience of a certain activity, and adoption of general collaboration rules by the team) [17]. J.R. Hackman (2005), R.M. Gillies and M. Boyle (2010) conclude that group work contributes to effective acquisition of academic knowledge and development of interpersonal communication skills [18, 19]. E.F. Barkley, C.H. Major, and K.P. Cross (2014) instruct on small student grouping, the distribution of roles, the development of team spirit, addressing unexpected problems, and assessing students involvement in addressing team assignments in the recommendations for teachers on organization and resourcing of effective collaborative classes. The authors also call attention to the role of faculty in the organization of learning activity, the need to combine individual and collaborative responsibility in grading group learning activities [20].

According to L. Rabekova and J. Hvorecky (2015), the collaborative learning activity is one of the components of various student learning techniques intended for improvement of the quality of their professional training [21].

As we see, researchers consider group learning activities mainly as the external side of the educational process, the framework of which makes interactive learning possible. The fundamental difference of our approach consists in the idea that learning in a small group is considered as the activity of a uniform group subject, which is a way of acquisition of the expected result. Therefore, it is about a group learning technique. From the author's point of view, the student group learning technique is a scientifically based, clearly planned, substantively, methodically and procedurally supported process leading to achieving the expected result, which is the formation of general and professional competencies.

Study object is an inorganic chemistry teaching process at higher education institutions of Ukraine.

Study subject is a student group learning technique used for implementation of the competence-based approach to inorganic chemistry classes.

The purpose of the article is to explore a didactic potential of students' group learning activity in the implementation of a competence-based approach to inorganic chemistry learning process.

The article objectives are to justify the group learning technique in the inorganic chemistry learning process at higher pedagogical education institutions and to present quantitative and qualitative results of experimental verification of systematic use of group learning activity of students, future chemistry teachers, at inorganic chemistry laboratory practicals.

Structure of the article. The article consists of four parts. The first part presents the conceptual foundations of the group learning activity of students, the relevance of the topic, its object, subject and purpose. The second part describes the methods and material of the study and explains tailoring the pedagogical experiment conducted at the Mykhailo Kotsiubynskyi Vinnytsia State Pedagogical University with involvement of students of the first (High-School Instruction (Natural Science)) and the second (High-School Instruction (Human Biology and Health, Chemistry)) courses. The third part describes the results of the pedagogical experiment. The fourth part is inclusive of conclusions basing on the results of the study.

\section{Experimental}

To achieve the goal and solve the tasks set, we used the methods of scholastic attainments: analysis, description, interpretation, measurement, survey, questionnaire, test method, the study of educational documentation and documents regulating the teaching activities of the academic staff, the study of pedagogical experience, experiment, comparison, generalization of the data obtained and mathematical processing thereof.

Let's further characterize the organization of experimental learning. We guess the student group learning technique has significant didactic potential for development of both subject and general competencies of a 
future specialist. We consider subject competency of inorganic chemistry students as a dynamic combination of knowledge, skills, methods of activity and values in the field of inorganic chemistry, which determines the ability of students to further effective learning and professional activity. We distinguish cognitive, activityand value-based components in its structure. Below we provide an example of subject competency components presented as the results of studying the Hydrogen topic [22].

Cognitive component presumes the following actions: a student names hydrogen isotopes and compounds; gives examples of hydrogen production reactions; describes the properties and distribution of hydrogen in the nature and classification of hydrogen compounds of chemical elements.

Activity-based component presumes the following actions: the student compiles electronic and graphic formulas of the hydrogen atom, the equations of chemical reactions characteristic of hydrogen and appropriate schemes of electronic balances; substantiates the place of hydrogen in the periodic system, its valency and oxidation number; characterizes hydrogen by its place in the periodic system and atomic structure; experimentally produces, collects and checks hydrogen for purity; follows the rules of safe hydrogen handling; solves computational and experimental tasks.

Value-based component consists of the following actions: the student evaluates the role of hydrogen as an environmentally friendly fuel; proves the practical significance of hydrogen and its compounds; comprehends the need to preserve his/her own health and the environment when using chemical compounds and the importance of acquired knowledge for future professional activities.

The curriculum of Vinnytsia State Pedagogical University, the experiment home, provided 120 hours ( 4 credits) for studying the Inorganic Chemistry discipline, of which 24 hours were lectures, 40 hours - laboratory practicals, and 56 hours were assigned for the independent work. The final control point was a passfail exam.

Students independently shaped small learning groups consisting of 3-4 individuals of different progress in each group and elected a leader (consultant) in order to apply the group learning technique at the preparatory stage of the experiment. 'A consultant is a group student nominated as an unofficial leader, which is responsible for organization of collective activities for the most rapid and successful achievement of a goal' [5, p. 31]. All members of the small group acted in turn as a consultant throughout the inorganic chemistry study period in order to implement the principles of binary and professional orientation in teaching. The experimental technique presumed using both uniform (all groups perform the same task) and collaborative (each group performs part of a task common for the academic subgroup) group work.

At the preparatory stage, the academic staff drew up tasks for the group work, developed interdisciplinary communication cards for each topic, allowing to demonstrate the importance of learning material for further education and professional activities and secure interdisciplinary integration in order to develop students' ability to systemic, critical thinking; analysis and synthesis; application of knowledge in practical situations.

One laboratory class in inorganic chemistry with collaborative student activity is designed for 2 academic hours. There are the following stages of the laboratory class: motivation of collaborative activities; actualization of knowledge; application of knowledge and formation of skills; knowledge control; reflections of the group activity.

Let's consider the types of activities of the learning process members at each stage. At the motivation stage, the students attending the session consider and realize the purpose of the forthcoming collaborative activity, the ways of achieving the goals, and the significance of acquired educational results for the future professional activity. This is the shortest stage (3-5 minutes). The stage of knowledge actualization is designated for small learning groups. The consultant performs oral examination of students' theoretical knowledge on the class topic and puts the points scored in the account card. At this stage the learning material is complemented and updated through group learning activity in parallel with oral examination of knowledge and discussion of theoretical material. Meanwhile the teacher checks the students' performance of tasks of independent extracurricular assignment. The duration of the knowledge actualization stage is up to 20 minutes.

Students continue working in groups at the stage of application of knowledge and skill development: they perform tasks and carry out laboratory experiments. Tasks prepared by the teacher must meet the following requirements: consolidate the theoretical material of the topic; develop practical skills; promote development of the ability to put knowledge into practice; and be differentiated by complexity. The importance of this stage consists in promotion of a solid and conscious consolidation of theoretical knowledge, the formation of skills and proficiency, and development of value-based orientations. For this purpose, the group members work collaboratively and actively helping each other, using, where necessary, supporting notes, algorithms, textbooks and the like. Upon completion of the stage of knowledge application and formation of skills, the results of the 
collaborative class are summarized, collectively discussed, and, if necessary, corrected by the academic staff. The duration of the work of students in small learning groups at this stage is 35-40 minutes.

The consultant assesses the group's work. The following types of students' collaborative activities are subject to assessment: oral response at the stage of knowledge actualization; the quality of tasks performed at the stage of knowledge application and skill development.

The next stage is designated for individual control by a teacher and final evaluation of results achieved by students at the group laboratory class. At this stage, students individually complete written assignments or tests that allow the teacher to check subject competency under the conditions of collaborative learning. The duration of the knowledge control stage is about 15 minutes.

Upon completing the control assignments, students and the academic staff reflect on the progress and results of group learning activity. At this stage of the class, a value-based component of subject competency in inorganic chemistry is purposefully formed, as well as general competency (the ability to be critical and self-critical, the ability to evaluate and maintain the quality of work, etc.) is developed. The reflection lasts about 5 minutes. The final stage of the lab session is summarizing the results and informing the students of the next topic and the tasks of preparation for the next class (about 5 minutes).

From the standpoint of both parties of the educational process (students and academic staff), the group learning technique is actualized through interconnected actions aimed at achievement of the expected result (Fig. 1).

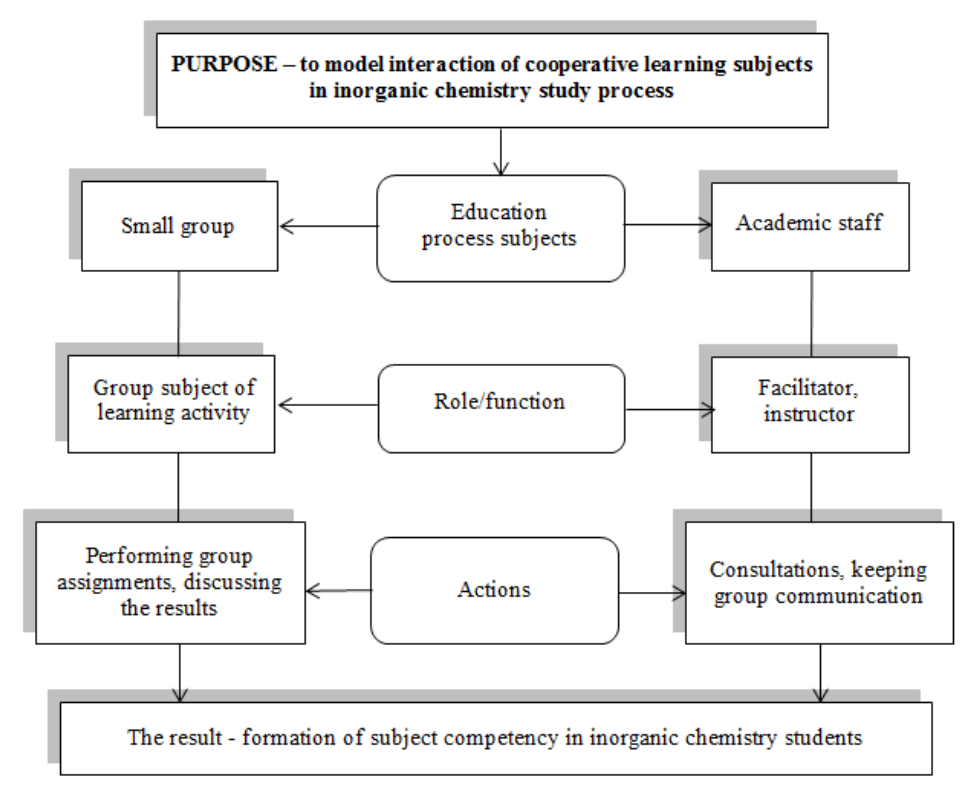

Figure 1. Scheme of interaction of group learning subjects

We designed an experiment to compare the performance of students in the flipped classroom with the traditional teaching. The pedagogical experiment involved 50 students, prospective teachers of Chemistry, including 24 students enrolled in the educational program «Secondary education (Biology and Human Health. Chemistry)» as an experimental group, and 26 students enrolled in the educational program «Secondary Education (Natural Sciences)» as a control group.

The effectiveness of students' group educational activities in the process of studying inorganic chemistry was determined by using the following criteria:

1) developing subject competence in inorganic chemistry;

2) students ' satisfaction with the progress and results of training in small groups.

At the stage of preparation for the pedagogical experiment, we analyzed the curriculum and found out what educational elements of the content of the discipline students have to learn. Under the educational element of the content, we understand the knowledge, skills, and values that are developed in the process of teaching inorganic chemistry. To get a complete picture of the effectiveness of the group learning technology proved in the research, we measured the subject competence for each component: cognitive (knowledge, concepts, facts, rules), activity (skills, methods of activity), and value (attitude, awareness). To identify the influence of group 
learning technology on shaping students' subject competence in inorganic chemistry, we conducted a statistical comparison of the results in the experimental and control groups.

We developed a test measuring and defining the level of the cognitive component of subject competence in inorganic chemistry. It contained 30 closed-form tasks of various types (multiple choice, determining the sequence, and matching). The test allowed us to check up 50 educational content elements that make up the students' subject (special) competence in inorganic chemistry. According to the educational programs «Secondary education (Biology and Human Health. Chemistry)», and «Secondary education (Nature Sciences)», the cognitive component of the subject competences is formed by knowledge of the properties of the elements, simple and complex inorganic substances; it includes the ability to use modern symbols and terminology in chemical language, and understand the traditional names and trivial nomenclature of inorganic compounds. In addition, it deals with the general structure and content of chemical sciences based on the teachings about the structure of matter, periodic changes in the properties of chemical elements and their compounds, about the direction of chemical reactions (chemical thermodynamics), rates of chemical processes (chemical kinetics) and their mechanisms.

We measured and defined the level of shaping the activity component of students' subject competence of inorganic chemistry by observing the chemical experiments done by students in laboratory classes, analyzing the way they solve chemical problems, do exercises, and perform cognitive tasks. Conclusions about forming the activity component were also based on the results of observing the students design an experiment plan, select the necessary equipment and reagents, assemble devices, do the experiment and formulate its results, write down the equations of chemical reactions, solve computational and experimental problems, and observe safety rules.

Shaping of the value component was proved by the students' attitude to inorganic chemistry as a source of knowledge, which not only increases their scientific potential, but also serves as a basis for successful teaching activities at school. Here are the examples of professionally oriented tasks for out-of-class work used to develop the value component of subject competence: 1 . Analyze and compare the program of the standard and advanced study of Chemistry concerning differences in inorganic chemistry knowledge level. 2. Using the school textbook of the 11th grade (profile level), read the content of one of the practical works in the section "Chemical Elements of Group V-A». Determine what knowledge and skills in the study of inorganic chemistry you need to prepare for this practical work with high school students.

The level of shaping the value component was determined based on the results of analyzing the information submitted by the student in their self-assessment map.

The effectiveness of students' group learning activity in the process of studying inorganic Chemistry by the criterion 'Student satisfaction with the course and results of learning in small groups' was determined according to Z.I. Vasilyeva's method presented in 'Assessment of Satisfaction with Different Aspects of Life' [23].

\section{Results and Discussion}

Below are Table 1 and Figure 2 that summarize the quantitative analysis of the results obtained.

Table 1

Inorganic chemistry subject competency maturity of students in experimental and control groups

\begin{tabular}{|c|c|c|c|c|c|c|c|c|c|c|c|c|}
\hline \multirow{4}{*}{$\begin{array}{l}\text { Maturity of subject } \\
\text { competency components }\end{array}$} & \multicolumn{12}{|c|}{ Subject competency components } \\
\hline & \multicolumn{4}{|c|}{ Cognitive } & \multicolumn{4}{|c|}{ Activity-based } & \multicolumn{4}{|c|}{ Value-based } \\
\hline & \multicolumn{2}{|c|}{$\begin{array}{l}\text { Experimental } \\
\text { group }\end{array}$} & \multicolumn{2}{|c|}{ Control group } & \multicolumn{2}{|c|}{$\begin{array}{c}\text { Experimental } \\
\text { group }\end{array}$} & \multicolumn{2}{|c|}{ Control group } & \multicolumn{2}{|c|}{$\begin{array}{l}\text { Experimental } \\
\text { group }\end{array}$} & \multicolumn{2}{|c|}{ Control group } \\
\hline & q-ty & $\%$ & q-ty & $\%$ & q-ty & $\%$ & q-ty & $\%$ & q-ty & $\%$ & q-ty & $\%$ \\
\hline Low & 4 & 16.6 & 6 & 23 & 5 & 20.8 & 5 & 19.2 & 2 & 8.3 & 9 & 34.6 \\
\hline Average & 6 & 25 & 10 & 38.4 & 5 & 20.8 & 12 & 46.1 & 5 & 20.8 & 7 & 26.9 \\
\hline Sufficient & 9 & 37.5 & 6 & 23.0 & 10 & 41.6 & 6 & 23 & 11 & 45.8 & 8 & 30.7 \\
\hline High & 5 & 20.8 & 4 & 15.4 & 4 & 16.6 & 3 & 11.5 & 6 & 25 & 2 & 7.69 \\
\hline
\end{tabular}




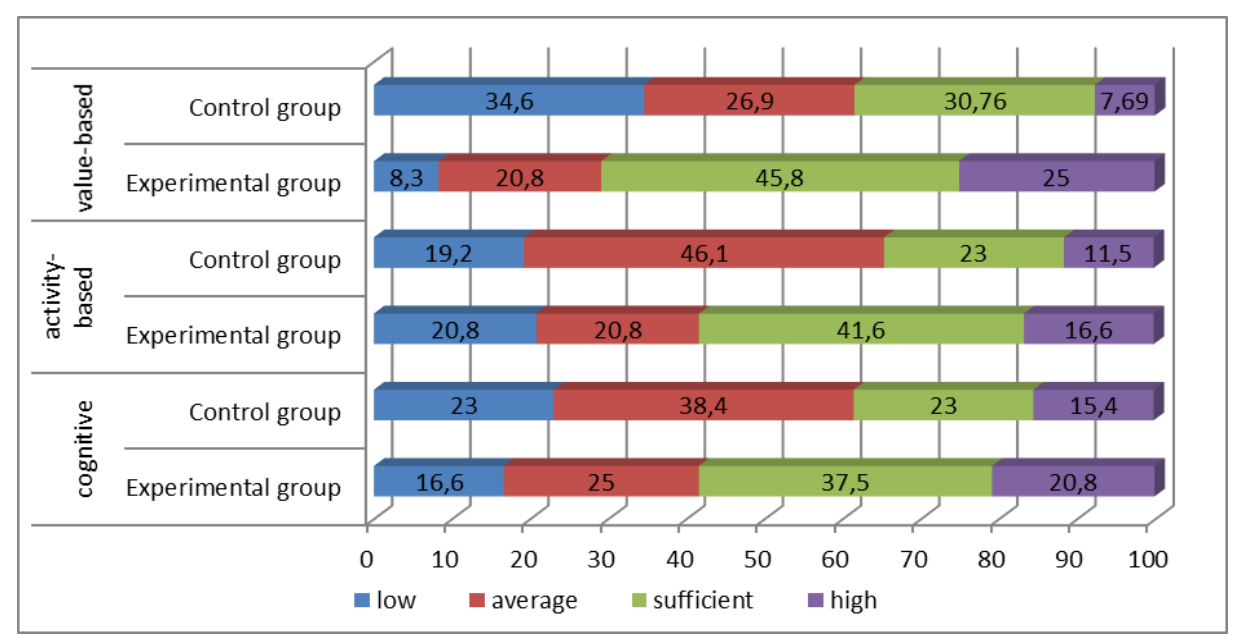

Figure 2. Inorganic chemistry subject competency component maturity of students in experimental and control groups

As you can see, the number of students with a sufficient and high level of subject competence in inorganic chemistry for all components in the experimental group is larger than in the control group.

A generalized indicator of shaping the cognitive component of the students' subject competence in inorganic chemistry was the coefficient of knowledge assimilation, which was 0.71 in the control group and 0.8 in the experimental group.

The generalized indicator of shaping the activity component of the students' subject competence in inorganic chemistry was chosen as the coefficient of mastering practical skills. In the control group, it was 0.64 and in the experimental group, it was 0.78 .

A general indicator of shaping the value component was the coefficient of students' awareness of the importance of knowledge in inorganic chemistry for further use in their future professional activities. This indicator was 0.82 in the experimental group and 0.7 in the control group.

We also made a comparative analysis of the results of the final assessment of students in the experimental and control groups for a course of inorganic chemistry, conducted according to the curriculum in the form of a test. The outcomes are shown in table 2 and graphically presented in the histogram (Fig. 3). As we can see, the results of the experimental group are higher in absolute and percentage terms.

Table 2

\section{Results of final attestation of inorganic chemistry students of experimental and control groups}

\begin{tabular}{|c|c|c|c|c|c|c|c|c|c|c|c|c|c|c|}
\hline \multirow{3}{*}{ Student group } & \multicolumn{14}{|c|}{ Number of students (Q-ty/\%) assessed under ECTS scale } \\
\hline & \multicolumn{2}{|c|}{$\mathrm{F}$} & \multicolumn{2}{|c|}{ FX } & \multicolumn{2}{|c|}{$\mathrm{E}$} & \multicolumn{2}{|c|}{$\mathrm{D}$} & \multicolumn{2}{|c|}{$\mathrm{C}$} & \multicolumn{2}{|c|}{$\mathrm{B}$} & \multicolumn{2}{|c|}{ A } \\
\hline & q-ty & $\%$ & q-ty & $\%$ & q-ty & $\%$ & q-ty & $\%$ & q-ty & $\%$ & q-ty & $\%$ & q-ty & $\%$ \\
\hline Experimental group & - & - & - & - & 5 & 20.8 & 5 & 20.8 & 3 & 12.5 & 6 & 25.0 & 5 & 20.8 \\
\hline Control group & - & - & - & - & 8 & 30.7 & 7 & 26.9 & 5 & 19.2 & 3 & 11.5 & 3 & 11.5 \\
\hline
\end{tabular}

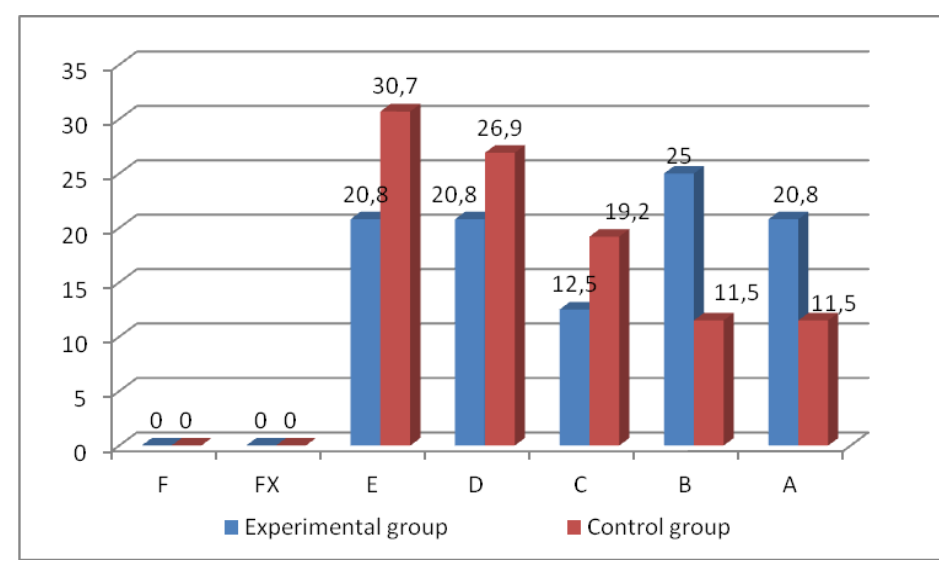

Figure 3. Results of final attestation of inorganic chemistry students of experimental and control groups 
For the purpose of a statistical conclusion on the reliability of the obtained results, Student's $t$-test was used for independent samples. The value of the $t$-test for the experimental sample is 0.843 . Comparing it with a tabular value at a significance level of 0.05 , we concluded that there is a difference between the experimental and control groups in shaping subject competence in inorganic chemistry.

The materials of the questionnaire survey of students, conversations with them, and observations of the teachers taking part in the experiment informed about the satisfaction of students in the experimental group with learning under experimental conditions. The coefficient of satisfaction with experimental training was quite high 0.9 .

The obtained results of the pedagogical experiment confirm the positive influence of group educational activities of students on shaping the subject competence in the process of teaching inorganic chemistry.

\section{Conclusions}

The results of the study provided the basis for the following conclusions. The didactic potential of group educational activities is diverse, which allows to develop effectively knowledge, skills, methods of activity and values, as well as students' communication skills. The work of students in small educational groups increases the motivation for studying inorganic chemistry, actualizes existing knowledge and promotes the development of new one, creates conditions for the acquisition and application of skills, and increases the accuracy of a chemical experiment.

The results obtained in the study of shaping the students' subject competence in inorganic chemistry for each of the components (cognitive, activity, value), student satisfaction with the course and learning outcomes of small groups indicate the multifunctional didactic potential of group educational activities. Its implementation in the process of teaching inorganic chemistry to future teachers increases the effectiveness of developing subject competence in inorganic chemistry provides optimization of the scientific, methodological and effective components of the educational process.

The scientific novelty of the study lies in the fact that for the first time, the technology of group training of students studying inorganic chemistry in institutions of higher pedagogical education is theoretically substantiated, methodically developed and experimentally tested.

The practical significance of the obtained results arises from the fact that scientific and pedagogical workers of higher education institutions can use the educational technology substantiated in the study as a methodological guide in their own teaching activities.

\section{References}

1 Компетентнісний підхід у сучасній освіті: світовий досвід та українські перспективи: бібліотека 3 освітньої політики / під заг. ред. О.В. Овчарук. — Київ: «К.І.С.», 2004. — 112 с.

2 Закон України «Про освіту». — URL: https://zakon.rada.gov.ua/laws/show/2145-19.

3 Методичні рекомендації щодо розроблення стандартів вищої освіти. — URL: https://mon.gov.ua/storage/app/media/ vishcha-osvita/rekomendatsii-1648.pdf

4 Ярошенко О.Г. Педагогічні основи групової навчальної діяльності школярів (на матеріалі вивчення хімії): дис. ... д-ра пед. наук: $13.00 .01 ; 13.00 .02$ / О.Г. Ярошенко. — Київ, 1998. — 382 с.

5 Ярошенко О.Г. Проблеми групової навчальної діяльності школярів: дидактико-методичний аспект / О.Г. Ярошенко. - Київ: Станіца, 1999. - 245 с.

6 Ярошенко О.Г. Групова робота учнів на семінарських заняттях з хімії. 8-9 кл.: метод. пос. для вчителів / О.Г. Ярошенко, О.А. Блажко. — Київ: Станіца-Київ, 2006. — 119 с.

7 Ярошенко О.Г. Зошит для практичних робіт і тематичного контролю знань з хімії. 9 клас / О. Г. Ярошенко, Т.В. Коршевнюк. - Київ: Станіца, 2009. - 80 c.

8 Блажко А.В. Хімія: зошит для лабораторних дослідів і практичних робіт для учнів професійно-технічних навчальних закладів кулінарного профілю / А.В. Блажко, О.Г. Ярошенко. — Вінниця: ТОВ «Нілан-ЛТД», 2015. — 64 с.

9 Ярошенко О.Г. Робочий зошит із хімії. 9 клас: навч посіб. для 9 кл. загальноосвітніх навч. закл. / О.Г. Ярошенко. Київ: УОВЦ «Оріон», 2017. - 144 с.

10 Ярошенко О.Г. Хімія. 11 кл.: підр для закл. загальної середньої освіти. - Київ: УОВЦ «Оріон», 2019. — 208 с.

11 Блажко О.А. Організація пізнавальної діяльності учнів основної школи 3 початковим рівнем досягнень у навчанні хімії: дис. ... канд. пед. наук: 13.00 .02 / О.А. Блажко. — Київ, 2006. - 178 с.

12 Коршевнюк Т.В. Формування знань старшокласників про молекулярні основи життя в процесі навчання біології: дис. ... канд. пед. наук: 13.00.02 / Т.В. Коршевнюк. — Київ, 2007. — 214 с.

13 Галацин К. Групові форми організації пізнавальної діяльності студентів - майбутніх інженерів - на заняттях 3 англійської мови / К. Галацин // Наук. вісн. Східноєвропейського національного університету імені Лесі Українки: Пед. науки. - 2015. — № 1. - С. 42-45. 
14 Морзе Н.В. Формування навичок ефективної співпраці студентів під час використання вікі-порталу / Н.В. Морзе,

Л.О. Варченко-Троценко // Інформаційні технології і засоби навчання. — 2014. — Вип. 2., № 40. — С. $92-106$. $291 \mathrm{c}$.

15 Кручек В.А. Психолого-педагогічні основи міжособистісного спілкування / В.А. Кручек. — Київ: НФКККіМ, 2011. -

16 Ярошенко О.Г. Навчальне спілкування студентів як чинник підготовки фахівців у вищих навчальних закладах / О.Г. Ярошенко // Психолого-педагогічні засади проектування інноваційних технологій навчання у вищій школі: монографія / В. Луговий, М. Левшин, О. Бондаренко та ін.; за заг. ред. В.П. Андрущенка, В.І. Лугового. - Київ: Педагогічна думка, 2011. - C. 123-144.

17 Hammar Chiriac E. Group work as an incentive for learning - students' experiences of group work / E. Hammar Chiriac // Front. Psychol. — 2014. — No. 5. - P. 558. doi:10.3389/fpsyg.2014.00558

18 Hackman J. R. A Theory of Team Coaching / J.R. Hackman, R. Wageman // Academy of Management Review. - 2005. No. 2. - P. 269-287. doi:10.5465/AMR.2005.16387885

19 Gillies R.M. Teachers' reflections on cooperative learning: Issues of implementation / R.M. Gillies, M. Boyle // Teaching and Teacher Education. - 2010. — Vol. 26, No. 4. - P. 933-940. doi:10.1016/j.tate.2009.10.034.

20 Barkley E.F. Collaborative learning techniques: A handbook for college faculty (2nd ed.) / E.F. Barkley, C.H. Major, K.P. Cross. - San Francisco: Jossey-Bass. 2014. — URL: http://citeseerx.ist.psu.edu/viewdoc/download? doi=10.1.1.891.3008 $\&$ rep=rep $1 \&$ type $=$ pdf

21 Rabekova L. Learning Strategies for Small Groups of Professionals / L. Rabekova, J. Hvorecky // Proceedings of 2015 international conference on interactive collaborative learning (ICL). — 2015. — P. 764-770. doi: 10 1109/ICL.2015.7318125.

22 Блажко А.В. Неорганічна хімія: навчальна програма для студентів спеціальності 014.05 Середня освіта (Біологія та здоров'я людини) / А.В. Блажко. - Вінниця: ВДПУ, 2017. - 20 с.

23 Васильева 3.И. Изучение личности школьника учителем / З.И. Васильева, Н.В. Бочкина, Е.С. Заир-Бек и др.; под ред. 3.И. Васильевой. - М.: Педагогика, 1991. - 135 с.

\author{
О.Г. Ярошенко, О.А. Блажко, А.В. Блажко, Т.В. Коршевнюк
}

\title{
Топтық оқу іс-әрекеті университет студенттеріне бейорганикалық химияны оқытуда құзыреттілік тәсілді іске асырудың шарты ретінде
}

\begin{abstract}
Мақалада бейорганикалық химияны оқыту барысында университет студенттерінің топтық оқу іс-әрекетінің тиімділігінің тәжірибелік тексеру нәтижелері келтірілген. Эксперименттік оқыту ғылыми жұмыстарды талдау деректеріне және Украинада қалыптасқан окушылардың топтық оқу іс-әрекетінің тұжырымдамасын іске асыру тәжірибесіне негізделген технология бойынша жүзеге асырылған. Студенттерді топтық оқыту технологиясында білім беру нәтижелерін жалпы және арнайы (кәсіптік, пәндік) құзыреттіліктер түрінде алу қарастырылған. Субъекті студенттердің шағын топтары болып табылатын бейорганикалық химия бойынша зертханалық сабақтарды дайындау және өткізу қысқаша сипатталған. Педагогикалық университетте «Бейорганикалық химия» пәні бойынша зертханалық сабақтарда топтық оқыту субъектілерінің қызметінің ерекшеліктері ашылған. Өткізілген педагогикалық эксперименттің ұйымдастырылуы, барысы және нәтижелері ұсынылған. Алынған нәтижелер негізінде жасалған негізгі қорытынды - университет студенттерін оқытуда топтық іс-әрекетті пайдалану бейорганикалық химия бойынша білім беру үдерісінде құзыреттілік тәсілді жүзеге асырудың тиімді шарты болып табылады. Шағын топтарды оқыту бейорганикалық химия бойынша сабақтарды ұйымдастыруды және өткізуді оңтайландырады, студенттердің кәсіби құзыреттілігін қалыптастыруға оң әсерін тигізеді. Сонымен қатар, басқа оқу пәндері бойынша зертханалық сабақтарда жоғары білім алушылардың топтық оқу қызметін жүйелі түрде пайдаланудың орындылығы туралы қорытынды жасалған. Студенттерге химиялық білім беруде құзыреттілік тәсілді іске асыру мақсатында топтық оқытуды пайдалану ғылыми-педагогикалық қызметкерлерден белгілі бір әдістемелік дайындықты талап ететіндігі атап өтілген.
\end{abstract}

Кілт сөздер: құзыреттілік тәсіл, «Бейорганикалық химия» оқу пәні, топтық оқу іс-әрекеті, топтық оқыту технологиясы, топтық оқыту субъектісі, студенттер, ғылыми-педагогикалық қызметкерлер, зертханалық сабақтар.

\section{О.Г. Ярошенко, О.А. Блажко, А.В. Блажко, Т.В. Коршевнюк}

\section{Групповая учебная деятельность как условие реализации компетентностного подхода в обучении неорганической химии студентов университета}

\footnotetext{
В статье приведены результаты экспериментальной проверки эффективности групповой учебной деятельности студентов университета в процессе изучения неорганической химии. Экспериментальное обучение осуществлялось по технологии, обоснованной с учетом данных анализа научных работ и сложившейся в Украине практики реализации концепции групповой учебной деятельности школьников. Технологией группового обучения студентов предусмотрено получение образовательных результатов
} 
в виде общих и специальных (профессиональных, предметных) компетентностей. Кратко описаны подготовка и проведение лабораторных занятий по неорганической химии, субъектами которых являются малые группы студентов. Раскрыты особенности деятельности групповых субъектов обучения на лабораторных занятиях по учебной дисциплине «Неорганическая химия» в педагогическом университете. Представлены организация, ход и результаты проведенного педагогического эксперимента. Основной вывод, сделанный на основе полученных результатов, использование групповой учебной деятельности студентов университета является эффективным условием реализации компетентностного подхода в образовательном процессе по неорганической химии. Обучение малыми группами оптимизирует организацию и проведение занятий по неорганической химии, положительно сказывается на формировании профессиональных компетентностей студентов. Сделан также вывод о целесообразности систематического использования групповой учебной деятельности соискателей высшего образования на лабораторных занятиях по другим учебным дисциплинам. Отмечено, что использование группового обучения с целью реализации компетентностного подхода в химическом образовании студентов требует от научно-педагогических работников определенной методической подготовки.

Ключевые слова: компетентностный подход, учебная дисциплина «Неорганическая химия», групповая учебная деятельность, технология группового обучения, групповой субъект обучения, студенты, научно-педагогические работники, лабораторные занятия.

\section{References}

1 Ovcharuk, O.V. (2004). Kompetentnisnyi pidkhid u suchasnii osviti: svitovyi dosvid ta ukrainski perspektyvy [A competency approach in modern education: world experience and Ukrainian perspectives]. Kyiv: «K.I.S.» [in Ukrainian].

2 Zakon Ukrainy «Pro osvitu» [The Law of Ukraine «On Education»]. (n.d.). zakon.rada.gov.ua. Retrieved from https://zakon.rada.gov.ua/laws/show/2145-19 [in Ukrainian].

3 Metodychni rekomendatsii shchodo rozroblennia standartiv vyshchoi osvity [Guidelines for the development of higher education standards]. (n.d.). mon.gov.ua. Retrieved from https://mon.gov.ua/storage/app/media/vishcha-osvita/rekomendatsii-1648.pdf [in Ukrainian].

4 Yaroshenko, O.H. (1998). Pedahohichni osnovy hrupovoi navchalnoi diialnosti shkoliariv (na materiali vyvchennia khimii) [Pedagogical bases of group educational activity of students (on the material of study of chemistry)]. Doctor's thesis. Kyiv [in Ukrainian].

5 Yaroshenko, O.H. (1999). Problemy hrupovoi navchalnoi diialnosti shkoliariv: dydaktyko-metodychnyi aspect [Problems of group educational activity of pupils: didactic-methodical aspect]. Kyiv: Stanitsa [in Ukrainian].

6 Yaroshenko, O.H., \& Blazhko, O.A. (2006). Hrupova robota uchniv na seminarskykh zaniattiakh z khimii. 8-9 kl. [Group work of students in seminars on chemistry. 8-9 cells]. Kyiv: Stanitsa-Kyiv [in Ukrainian].

7 Yaroshenko, O.H., \& Korshevniuk, T.V. (2009). Zoshyt dlia praktychnykh robit i tematychnoho kontroliu znan z khimii. 9 klas. [Workbook for practical work and thematic control of knowledge in chemistry. Grade 9]. Kyiv: Stanitsa [in Ukrainian].

8 Blazhko, A.V., \& Yaroshenko, O.H. (2015). Khimiia: zoshyt dlia laboratornykh doslidiv i praktychnykh robit dlia uchniv profesiino-tekhnichnykh navchalnykh zakladiv kulinarnoho profiliu [Chemistry: a notebook for laboratory experiments and practical work for students of vocational schools of culinary profile]. Vinnitsa: TOV «Nilan-LTD» [in Ukrainian].

9 Yaroshenko, O.H. (2017). Robochyi zoshyt iz khimii. 9 klas [Workbook in chemistry. Grade 9]. Kyiv: Stanitsa [in Ukrainian].

10 Yaroshenko, O.H. (2019). Khimiia. 11 kl.: pidr dlia zakl. zahalnoi serednoi osvity. [Chemistry. 11 cl.: padr for lock. general secondary education]. Kyiv: UOVTs «Orion» [in Ukrainian].

11 Blazhko, O.A. (2006). Orhanizatsiia piznavalnoi diialnosti uchniv osnovnoi shkoly z pochatkovym rivnem dosiahnen u navchanni khimii [Organization of cognitive activity of elementary school students with an initial level of achievement in chemistry teaching]. Candidate's thesis. Kyiv [in Ukrainian].

12 Korshevniuk, T.V. (2007). Formuvannia znan starshoklasnykiv pro molekuliarni osnovy zhyttia v protsesi navchannia biolohii: [Formation of knowledge of high school students about the molecular basis of life in the process of teaching biology]. Candidate's thesis. Kyiv [in Ukrainian].

13 Halatsyn, K. (2015). Hrupovi formy orhanizatsii piznavalnoi diialnosti studentiv - maibutnikh inzheneriv - na zaniattiakh z anhliiskoi movy [Group forms of organization of cognitive activity of students — future engineers — in English classes]. Naukovyi visnyk Skhidnoievropeiskoho natsionalnoho universytetu imeni Lesi Ukrainky. Pedahohichni nauky - Scientific Bulletin of the East European Lesya Ukrainka National University: Pedagogical Sciences, 1, 42-45 [in Ukrainian].

14 Morze, N.V., \& Varchenko-Trotsenko, L.O. (2014). Formuvannia navychok efektyvnoi spivpratsi studentiv pid chas vykorystannia viki-portalu [Developing students' effective collaboration skills while using the wiki portal]. Informatsiini tekhnolohii $i$ zasoby navchannia - Information technology and training tools, 2, 4, 92-106 [in Ukrainian].

15 Kruchek, V.A. (2011). Psykholoho-pedahohichni osnovy mizhosobystisnoho spilkuvannia [Psychological and pedagogical foundations of interpersonal communication]. Kyiv: NFKKKiM [in Ukrainian].

16 Yaroshenko, O.H. (2011). Navchalne spilkuvannia tudentiv yak chynnyk pidhotovky fakhivtsiv u vyshchykh navchalnykh zakladakh [Educational communication of students as a factor of training of specialists in higher educational establishments] Psykholoho-pedahohichni zasady proektuvannia innovatsiinykh tekhnolohii navchannia u vyshchii shkoli-Psychological and pedagogical principles of designing innovative teaching technologies in higher education. V. Luhovyi, M. Levshyn, O. Bondarenko (Ed.); Kyiv: Pedahohichna dumka [in Ukrainian].

17 Hammar Chiriac E. (2014). Group work as an incentive for learning - students' experiences of group work. Front. Psychol, 5, 558. doi:10.3389/fpsyg.2014.00558 
18 Hackman, J.R., \& Wageman, R. (2005). A Theory of Team Coaching. Academy of Management Review, 2, $269-287$. doi:10.5465/AMR.2005.16387885

19 Gillies, R.M., \& Boyle, M. (2010). Teachers' reflections on cooperative learning: Issues of implementation. Teaching and Teacher Education, 26(4), 933-940. doi:10.1016/j.tate.2009.10.034.

20 Barkley, E.F., Major, C.H., \& Cross, K.P. (2014). Collaborative learning techniques: A handbook for college faculty (2nd ed.). San Francisco: Jossey-Bass. http://citeseerx.ist.psu.edu/viewdoc/download? doi=10.1.1.891.3008\&rep=rep1\&type=pdf

21 Rabekova, L., \& Hvorecky, J. (2015). Learning Strategies for Small Groups of Professionals. Proceedings of 2015 international conference on interactive collaborative learning (ICL), 764-770. doi: 10 1109/ICL.2015.7318125.

22 Blazhko, A.V. (2017). Neorhanichna khimiia: navchalna prohrama dlia studentiv spetsialnosti 014.05 Serednia osvita (Biolohiia ta zdorovia liudyny). [Inorganic Chemistry: Curriculum for Specialty Students 014.05 Secondary Education (Biology and Human Health)]. Vinnitsa: VDPU [in Ukrainian].

23 Vasyleva, Z.I., Bochkina, N.V., \& Zayr-Bek, E.S., et al. (1991). Izuchenie lichnosti shkolnika uchitelem [Teacher studying personality of a schoolboy]. Moscow: Pedahohika [in Russian]. 